\title{
A NUMERICAL STUDY OF THE PLATA RIVER PLUME ALONG THE SOUTHEASTERN SOUTH AMERICAN CONTINENTAL SHELF
}

\author{
Felipe M. Pimenta ${ }^{1 *}$, Edmo José Dias Campos ${ }^{l^{*}}$, Jerry L. Miller ${ }^{2 *}$ \& Alberto R. Piola ${ }^{3 *}$ \\ ${ }^{1}$ Instituto Oceanográfico da Universidade de São Paulo \\ (Praça do Oceanográfico, 191 05508-900, São Paulo, SP, Brasil) \\ ${ }^{2}$ Naval Research Laboratory \\ (Code 7332, Stennis Space Center, U.S.A.) \\ ${ }^{3}$ Universidad de Buenos Aires \\ Depto. de Oceanografia, Servício de Hidrografia Naval and \\ Depto. Ciências de la Atmósfera y los Océanos, Buenos Aires, Argentina
}

\section{A B S TR A C T}

The Rio de la Plata, one of the largest rivers on Earth, discharges into the ocean waters from basin that covers a large area of South America. Its plume extends along northern Argentina, Uruguay, and southern Brazil shelves strongly influencing the ecosystems. In spite of this, little is known about the mechanisms that control it. Here we report results of simulations with POM carried out to investigate the roles of wind and river discharge in Plata plume dynamics. Different outflows were explored, including an average climatological value and magnitudes representative of La Niña and El Niño. Forcing the model with river discharge the average plume speed was directly related to the outflow intensity. The Plata northward extension varied from 850 to $1550 \mathrm{~km}$ and for average discharge a band of low salinity waters formed from the estuary up to $30^{\circ} \mathrm{N}$ of South Brazilian Shelf. Upwelling and downwelling winds were applied after 130 days. The distribution of low salinity waters over the shelf was more sensitive to the wind direction than to the river outflow variability. Downwelling winds were very capable of advecting the low salinity signal downshelf. Upwelling winds were efficient in eroding the plume, which was basically detached from the coast by Ekman drift. Abnormal plume intrusions toward low latitudes may be a result of the original plume position coupled with events of persistent strong downwelling favorable winds.

\section{R ESUMO}

O Rio da Prata, um dos maiores rios da Terra, descarrega no oceano águas de uma bacia de drenagem que cobre uma ampla área da América do Sul. Sua pluma extende-se ao longo do norte da Argentina, Uruguay e sul do Brasil influenciando amplamente os ecossistemas costeiros. A despeito disso, pouco se sabe a respeito dos mecanismos que a controlam. Relatamos aqui simulações conduzidas com o modelo POM na investigação do papel dos ventos e da descarga fluvial na dinâmica da pluma do Prata. Descargas com valores médios climatológicos e magnitudes representativas de El Niño e La Niña foram explorados. Somente sob descarga fluvial, a velocidade média de penetração da pluma ao longo da costa foi diretamente relacionada à vazão. Sua extensão variou entre 850 e $1550 \mathrm{~km}$ e no caso da vazão média uma banda de baixa salinidade formou-se desde o estuário até $30^{\circ} \mathrm{N}$ na plataforma continental sul brasileira. $\mathrm{O}$ efeito de ventos de sudoeste, que causam subsidência, e de nordeste, que promovem a ressurgência costeira, foram investigados após 130 dias de descarga fluvial. Os resultados sugerem que a distribuição de baixa salinidade é muito mais sensível à direção dos ventos do que à descarga fluvial. Ventos de sudoeste são capazes de advectar o sinal de baixa salinidade ao longo da costa. Já os ventos de nordeste demonstram ser eficientes na erosão da pluma, que é destacada da costa por deriva de Ekman. Uma intrusão anormal da pluma de baixa salinidade em direção a baixas latitudes pode ser o resultado da posição original da pluma acoplada a eventos persistentes de fortes ventos de sudoeste.

Descriptors: Eastern South America Continental Shelf, South Brazilian Shelf, Rio de la Plata, South Brazil Bight, Buoyancy Plume, Princeton Ocean Model.

Descritores: Plataforma continental leste Sul Americana, Plataforma continental Sul Brasileira, Bacia de Santos, Rio da Prata, pluma costeira, modelagem hidrodinâmica.

(*) Now at the Graduate College of Marine Studies, University of Delaware, Newark, Delaware, 19716, U.S.A. Email addresses: felipe@udel.edu (Felipe M. Pimenta), edmo@io.usp.br (Edmo J. D. Campos), jmiller@nrlssc.navy.mil (Jerry L. Miller), apiola@ hidro.gov.ar (Alberto R. Piola).

Contr. No. 869 do Inst. oceanogr. da Usp. 


\section{INTRODUCTION}

The intermittent intrusion of relatively fresh cold waters from higher latitude into the South Brazil Bight (SBB), between $28^{\circ} \mathrm{S}$ and $22^{\circ} \mathrm{S}$ off the Brazilian coast, is a phenomenon that has intrigued the scientific community. This phenomenon has been known for a long time but was first documented in the scientific literature in the middle 90's (Campos et al., 1995, 1996a,b). Combining in situ measurements and satellite imagery, these studies demonstrated the presence of cold $\left(\mathrm{T} \sim 18^{\circ} \mathrm{C}\right)$ low salinity $(\mathrm{S} \sim 32)$ waters extending from south of the Cape of Santa Marta $\left(28^{\circ} \mathrm{S}\right)$ to the middle of the bight, at approximately $23^{\circ} 30^{\prime}$ 'S (Fig. 1). The absence of major river systems in the region and the thermohaline characteristics of the coastal waters excluded the possibility of influence of local river runoff or upwelling (Campos et al., 1996b).

Based on satellite SST images and trajectories of surface drifters launched in February and late April of 1993, the unexpected water mass was associated with advection from the vicinity of the Brazil-Malvinas Confluence (BMC) in the Argentinian continental shelf (Stevenson et al., 1998; Campos et al., 1996b). This water mass was suggested as the agent responsible for the failure of important Brazilian fisheries (Matsuura, 1996; Sunye \& Servain, 1998) and for the intrusion of organisms from different biogeographic zones. The detection of cold water foraminifera at unexpected low latitudes (Stevenson $e t$ al., 1998) and the anecdotal reports of the occasional appearance of penguins are some indicators. It's recurrence was studied by Campos et al. (1999) and Lentini et al. (2001) through the analysis of a 13-year time series of AVHRR images. Their findings revealed the cold intrusions as seasonal phenomenon, which presents an interannual variability possibly related to El Niño/Southern Oscillation (ENSO). At the same time, Piola et al. (2000) based on the analysis of historical hydrographic data described the presence of a defined seasonal sign associated with the Rio de la Plata surface plume. As one of the largest rivers on Earth, the Plata River (Plata hereafter) discharges into the ocean waters from a drainage basin that covers nearly $20 \%$ of South America. The influence of its plume, as suggested by the historical data, extends into the continental shelf off northern Argentina, Uruguay and southern Brazil. Sometimes the plume reaches latitudes as low as $27^{\circ} \mathrm{S}$ during the winter, while in the summer it is confined to $32^{\circ} \mathrm{S}$ (Piola et al., 1999, 2000).

The Plata discharge presents interannual variability related to El Niño scale rainfall variations over South America (Ropelewski \& Halpert, 1987; Grimm et al., 1998; Mechoso \& Iribarren, 1992; Depetris et al., 1996). This correlation was suggested as a reason for unusual plume intrusions along the shelf, which under high outflow events would explain the appearance of cold and fresh waters to SBB (Campos et al., 1999 and Piola et al., 2000). Surface salinity observations from Guerrero et al. (1997a) in late April and May of 1983 demonstrated how the 30 isohaline extended to about $150 \mathrm{~km}$ offshore and to

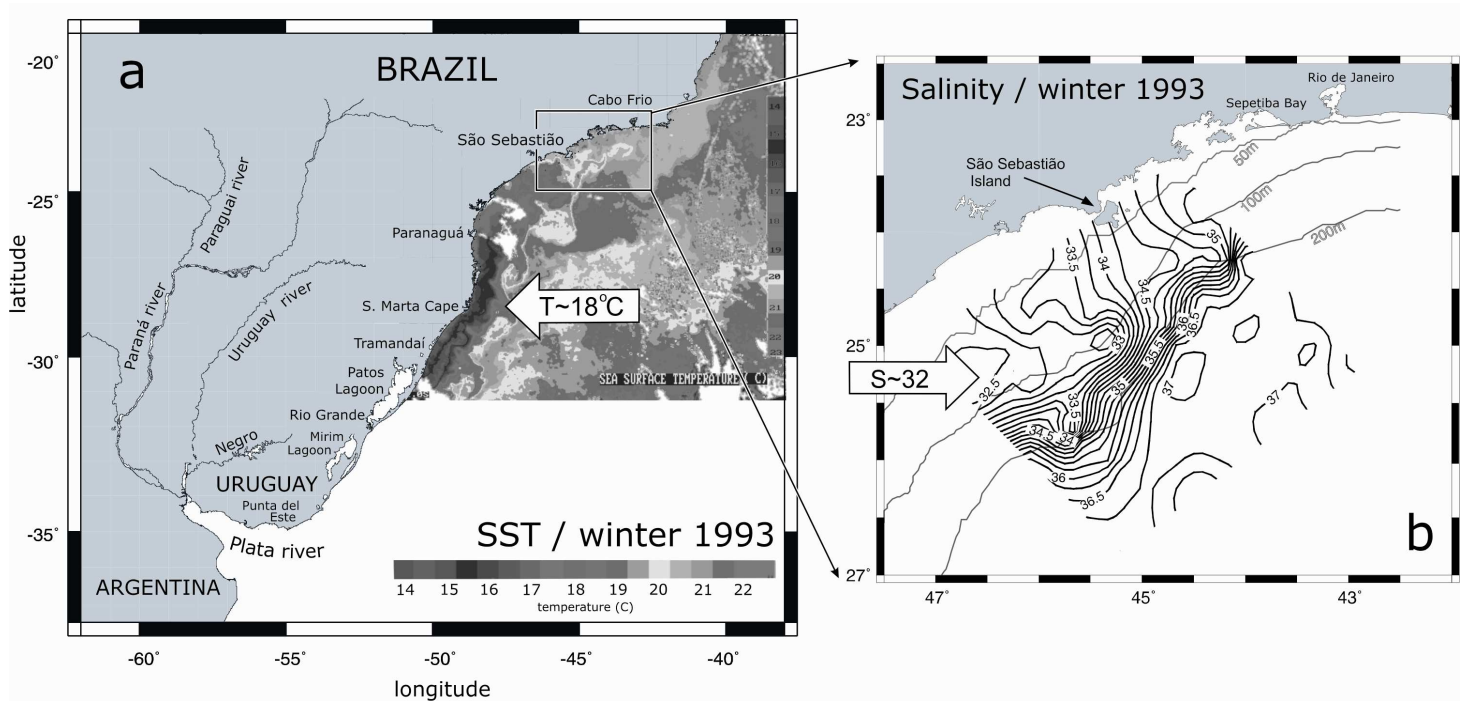

Fig. 1. a) Sea surface temperature (SST) derived from AVHRR/NOAA for July 1993. The dark colors indicate cold waters coming from the southwest into the area. b) Surface salinity field derived from COROAS-WOCE hydrographic 1993 winter cruise (Modified from Campos et al., 1999). 
$200 \mathrm{~km}$ along the coast of Uruguay beyond its average position during a high outflow event. The 1993 intrusion however, remains unclear. The change in the extent was of the order of 800 to $1000 \mathrm{~km}$, or nearly 4 times larger than observed by Guerrero et al. (1997a). Nevertheless, the anomalous northward penetration occurred about one year after a large river outflow event associated with the 1992-1993 El Niño.

Despite its considerable dimensions and strong influence on nearshore ecosystems (Ciotti et al., 1995; Mianzan et al., 2001), little is known about the Plata plume variability or mechanisms that control it A few numerical modeling studies investigated its seasonal variability (Simionato et al., 2001), and most of the investigations have focused on the estuarine domain (O'Connor, 1991; Framiñan \& Brown, 1996;
Guerrero et al., 1997a,b; Simionato et al., 2004). The phenomenon of coastal buoyant plumes, on the other hand, is well explored in the scientific literature. Works related to the Amazon River plume (Lentz, 1995; Limeburner et al., 1995; Geyer et al., 1996), the Delaware and Chesapeake systems (Münchow and Garvine, 1993; Rennie et al., 1999; Sanders and Garvine, 2001; Houghton et al., 2004), Columbia (Hickey et al., 1998) and the Rhine river plumes (Simpson and Souza, 1995) are some examples. These studies reveal the strong dependence that buoyant plumes demonstrate not only under river, but under wind forcing as well (Chao \& Boicourt, 1986; Chao, 1987, 1988a,b; Kourafalou et al., 1996a,b; Garvine, 1999).

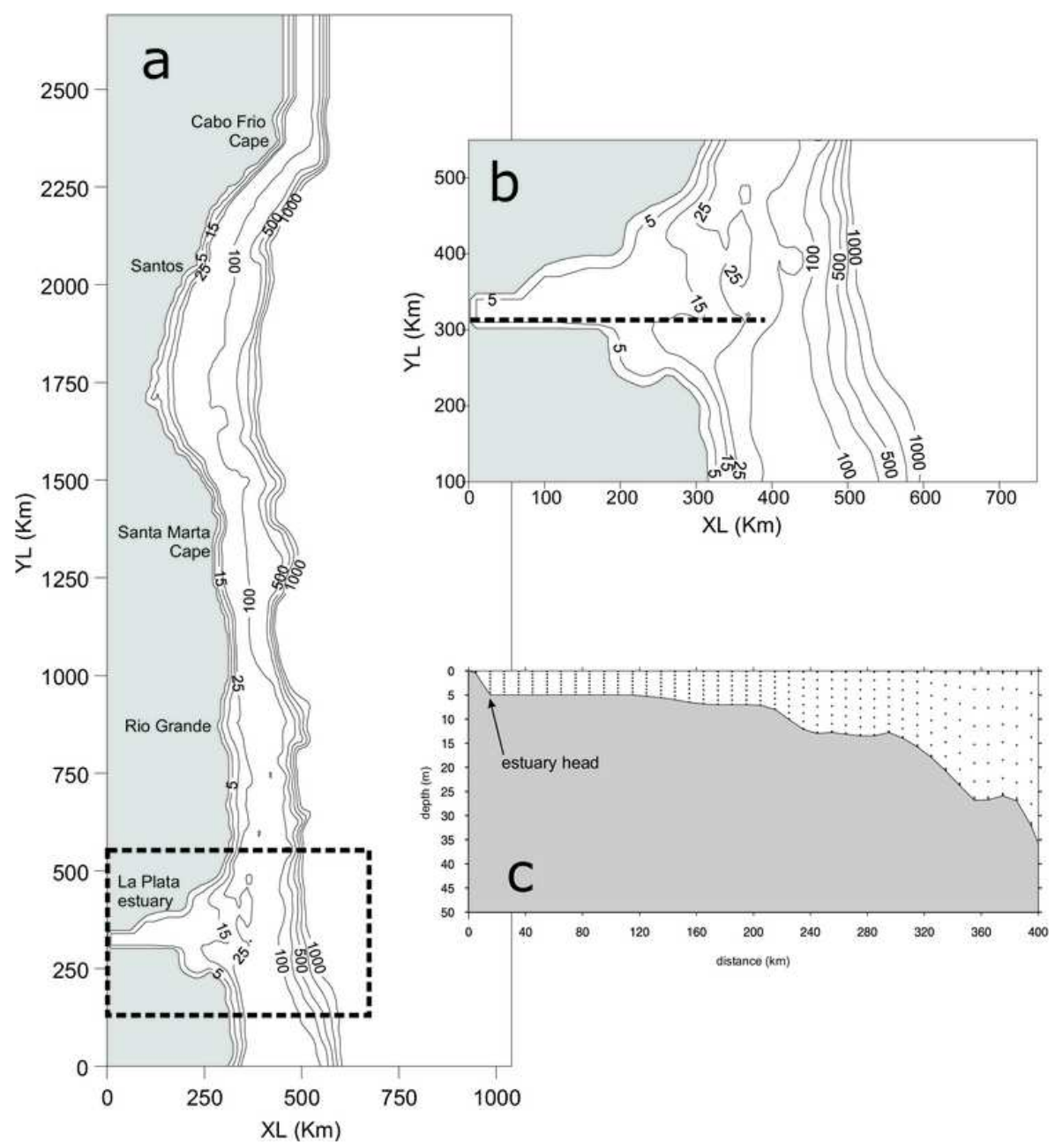

Fig. 2: a) Orthogonal rotated bathymetric domain, extending from south of Rio de la Plata estuary to Cabo Frio. b) Zoom at estuarine zone. c) Estuarine cross-section and sigma layers. 
Within this context, the objective of the present study is to extend the understanding on the Plata plume variability and investigate the relative roles of river discharge and wind forcing on the dynamics of the Plata river plume over the Southwestern Atlantic shelf. Specifically, we strove to explain plume intrusions to abnormal low latitudes. This research was based on simple numerical simulations of the Plata plume using the Princeton Ocean Model (POM).

\section{Methodology}

Buoyancy driven coastal plumes have been widely investigated by many researchers. These features are nonlinear, with Coriolis force and friction playing important roles (Csanady, 1984; Münchow \& Garvine, 1993; Kourafalou et al., 1996 b,a; Garvine, 1999). Here we adopted the Princeton Ocean Model (POM), a three-dimensional, sigma-coordinate, primitive equation model (Mellor, 1996; Blumberg \& Mellor, 1987).

\section{The Numerical Model}

The model dependent variables are the zonal, meridional and upward components of velocity ( $u, v, w$, respectively), the free surface elevation $\eta$, temperature $\mathrm{T}$, salinity $\mathrm{S}$, and two properties of the turbulence field (turbulent macro scale and kinetic energy). The density $\rho$ is computed from the equation of state. The system of equations include the nonlinear advective terms and the variables are computed integrating the continuity equation, the momentum equation, and two equations for advection-diffusion of heat and salt. For the horizontal grid, an "Arakawa C" differencing scheme is used. The horizontal time differencing scheme is explicit, whereas the vertical differencing is implicit, which eliminates time constraints for the vertical coordinate and permits the use of fine vertical resolution in surface and bottom layers. An imbedded second moment turbulent closure sub-model (Mellor \& Yamada, 1982) provides the vertical mixing coefficients, while the horizontal diffusion and viscosity coefficients are parameterized by the Smagorinsky formula (Blumberg \& Mellor, 1987).

\section{Domain Setting, Initial Conditions and River Forcing} Implementation

The model was implemented in a physical domain that encompasses the southeastern South American continental shelf from $40^{\circ} \mathrm{S}$ to $22^{\circ} \mathrm{S}$. The model domain is a regular orthogonal grid rotated $40^{\circ}$ from the north. The bathymetric data used in its construction were based on Brazilian Navy nautical charts, Argentinean Hydrographic Naval Service and the ETOPO5 database. The horizontal resolution was set to $d x=d y=10 \mathrm{~km}$, which resulted in a $105 \times 270$ points grid (Fig. 2a). With this spatial resolution, the Nyquist wavelength is of $20 \mathrm{~km}$, a bit larger than the local Rossby Radius of deformation. However, considering both the alongshelf and cross-shelf dimensions of the plume, the $10 \mathrm{~km}$ horizontal resolution is reasonable. Depths greater than $1000 \mathrm{~m}$ were set to $1000 \mathrm{~m}$ and the vertical structure was represented by 12 sigma surfaces (Fig. 2c). In the numerical simulations, the domain was initialized with a homogeneous structure, with $\mathrm{T}=25^{\circ} \mathrm{C}$ and $\mathrm{S}=35 \mathrm{psu}$. The Plata River outflow was implemented as an open boundary condition at the estuary head on the western side of the domain. Since the domain was rotated $40^{\circ}$ degrees, the estuary head fit well to the meridional domain axis (Fig. 2b). Thus, the horizontal barotropic velocities across the river mouth could be prescribed as:

$$
\bar{u}=\frac{Q}{A}, \quad \bar{v}=0
$$

where $\mathrm{A}$ is the area of the vertical section of the estuary head, and $\mathrm{Q}$ is the river discharge $\left[\mathrm{m}^{3} \cdot \mathrm{s}^{-1}\right]$. The free surface elevation is computed by the model, applying a no-gradient condition $\left(\eta_{\mathrm{B}-1}=\eta_{\mathrm{B}}\right.$, where $\mathrm{B}$ is the boundary index). Hydrographic data show that the water column at the estuary head is quasi homogeneous in temperature and salinity (Guerrero et al., 1997a,b). Temperature and salinity were specified using a temporal relaxation based on historical conditions of the Rio de la Plata winter temperature $\left(\mathrm{T}=14^{\circ} \mathrm{C}\right)$ and salinity $(\mathrm{S}=5 \mathrm{psu})$.

\section{Oceanic Boundary Conditions}

In addition to the river runoff specification as an open boundary condition at the estuary head, three oceanic open boundary conditions were implemented. At the cross-shore boundaries (north and south) the elevation was treated with a no gradient condition, while barotropic velocity components and the horizontal internal velocity $\mathrm{u}$ and $\mathrm{v}$ were calculated by the Sommerfeld radiation condition:

$$
\frac{\partial \phi}{\partial t}+C \frac{\partial \phi}{\partial y}=0
$$

where $\phi$ denotes the velocity component, $\mathrm{C}$ is the phase velocity, and $\mathrm{y}$ is the axis normal to the open boundary. The evaluation of $\mathrm{C}$ usually follows the shallow water wave velocity expression, but in this case, it was evaluated by a simple diagnostic version proposed by Orlanski (1976):

$$
C=\frac{\phi_{B-1}^{n-1}-\phi_{B-1}^{n+1}}{\phi_{B-1}^{n+1}+\phi_{B-1}^{n-1}-2 \phi_{B-2}^{n-1}}
$$


Here, the superscript denotes the time step, and the subscript the position related to the boundary. Once C is evaluated, the velocity component can be calculated at the next time step $n+1$ by:

$$
\phi_{B}^{n+1}=\frac{\phi_{B}^{n-1}(1-r)+2 \phi_{B-1}^{n}}{1+r} \text { with } \quad r=\left\{\begin{array}{ccc}
1 & \text { if } \quad C \geq 1 \\
C \text { if } & 0<C<1 \\
0 & \text { if } C \leq 0
\end{array}\right.
$$

At the eastern oceanic boundary, a similar implementation to the cross-shore boundaries was performed, but with the addition of a 10-point hyperbolic sponge layer for the velocity components. In that layer, the velocity components were progressively damped from their original value $\left(\phi_{\mathrm{B}-10}\right)$ inside of the domain, to $78 \%$ of their value near the boundary $\left(0.78 \phi_{\mathrm{B}-1}\right)$. An Orlanski scheme was applied at the eastern domain edge $\left(\phi_{\mathrm{B}}\right)$. For the temperature and salinity boundary conditions, an advection solution was used in order to allow the plume movement through the cross-shore boundaries:

$$
\frac{\partial S}{\partial t}+v \frac{\partial S}{\partial y}=0
$$

where $\mathrm{v}$ is the velocity component normal to the boundary, and $\partial / \partial y$ is the derivative in the normal direction. This equation was implemented through a scheme advanced in time and space, as described by Palma \& Matano (2000):

$$
\begin{aligned}
& S_{B}^{n+1}=S_{B}^{n}+r_{1}\left(S_{B}^{n}-S_{B-1}^{n}\right)+r_{2}\left(S_{e}^{n+1}-S_{B}^{n}\right) \\
& \text { where } \\
& r_{1}=0.5\left(\Delta t_{i} / \Delta y\right)\left(v_{B}^{n}+\left|v_{B}^{n}\right|\right) \\
& r_{2}=0.5\left(\Delta t_{i} / \Delta y\right)\left(v_{B}^{n}-\left|v_{B}^{n}\right|\right) .
\end{aligned}
$$

In these equations, $\mathrm{S}$ is the salinity, $\Delta \mathrm{ti}$ is the internal mode time step, $\Delta y$ is the meridional space resolution, $\mathrm{v}_{\mathrm{B}}$ is the normal velocity component of the boundary and $\mathrm{S}_{\mathrm{e}}$ is the prescribed external value. Temperature is treated in an identical fashion. On the eastern boundary, a simple no-gradient condition was applied for temperature and salinity, since it was far enough to ensure no influence on the plume.

\section{NUMERICAL EXPERIMENTS}

In the real ocean, estuarine plume dynamics are dictated by several factors. The river discharge interacts with the surrounding water, generating thermohaline gradients that drive the density circulation; the wind works by establishing subinertial coastal currents; the tides enhance vertical mixing; and nearby oceanic currents impose horizontal shear. Here we focused on only two forcing factors: the river outflow and the wind forcing. To understand the role of these mechanisms and to facilitate the interpretation the model runs were divided into two sets of experiments. First, we conducted simulations with different river outflows, and then combined river outflow with different scenarios of wind forcing.

\section{Experiments Forced Only with River Outflow}

In this set of experiments, we dealt with the buoyancy-driven force generated by the Plata discharge, which mixes with the surrounding oceanic waters. Our experiments were based on two major questions. (1) What would be the extent of the alongshelf penetration of the plume for a steady coastal buoyancy source? (2) How would the alongshelf penetration vary with increased or decreased river discharges?

To address these questions, we first ran three experiments with the following values of river discharge: $\mathrm{Q}=15 \times 10^{3} \mathrm{~m}^{3} \mathrm{~s}^{-1}$ (low); $\mathrm{Q}=25 \times 10^{3} \mathrm{~m}^{3} \mathrm{~s}^{-1}$ (medium); and $\mathrm{Q}=50 \times 10^{3} \mathrm{~m}^{3} \mathrm{~s}^{-1}$ (high). According to Mechoso and Iribarren (1992) and Depetris et al. (1996) these values are typical of a La Niña situation (dry season/lower discharge), to normal periods (average discharge), and to El Niño Events (higher discharge). Hereafter, we refer to these experiments as $\mathrm{R} 15, \mathrm{R} 25$ and R50. The river outflow was set to zero at initialization and allowed to grow linearly to the target value within one inertial period. The experiments were run for lengths of time enough for allowing the progression of the plume along the entire extent of the spatial domain. The results were analyzed by observing the spatial evolution of the 34.9 isohaline, as depicted in Figure 3. Within the first 20 days of integration, the plume remained confined to the estuarine domain, except for the higher outflow case (R50), when the 34.9 isohaline extended beyond Punta del Este during that period. In all cases, after reaching the shelf region, the plume turned anticlockwise, following the direction of propagation of coastally trapped waves. From that point on, the main difference among the three experiments was the northward extension of the plume. In the R15 experiment, after 80 days of simulation with the low river discharge the plume extremity reached latitude $34^{\circ} \mathrm{S}$, an extent of about $623 \mathrm{~km}$. In the R25 and R50 experiments, the distance from the plume extremity to the estuary head was $764 \mathrm{~km}$ and $1099 \mathrm{~km}$, respectively. On day 140, the R15 plume had reached the latitude of Rio Grande $\left(32^{\circ} \mathrm{S}\right)$, while the R25 plume extended to the northern limit of Patos Lagoon $\left(30^{\circ} \mathrm{S}\right)$. In R50, the plume reached $27^{\circ} \mathrm{S}$, past the Cape of Santa Marta Grande. The alongshelf plume penetration, as determined by the distance of the 34.9 isohaline from the estuary head, is represented in Figure 4a. Within the first $200 \mathrm{~km}$, inside the estuary, the propagation velocities of the plumes in the three 

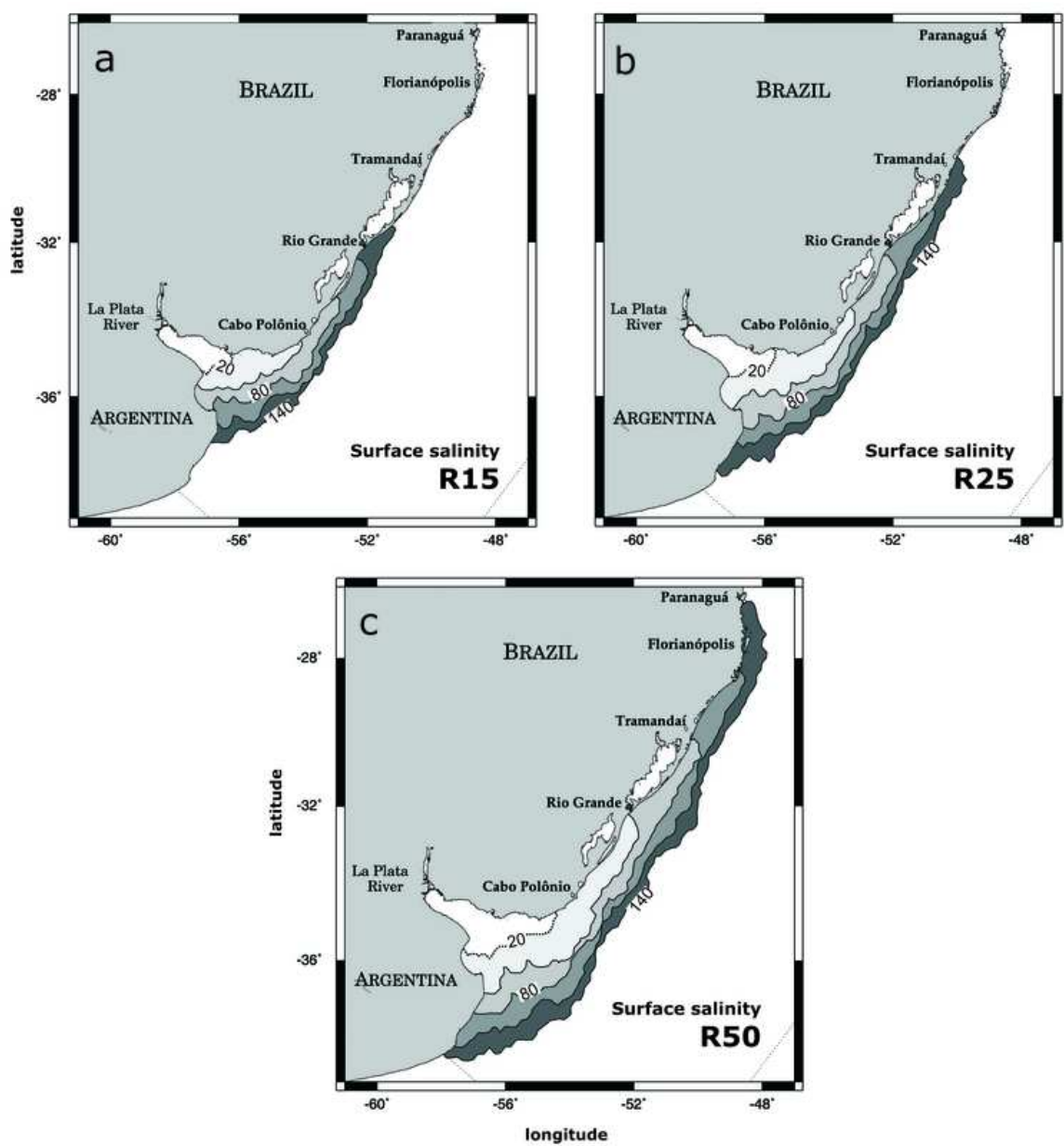

Fig. 3: Surface salinity field evolution for R15, R25 and R50 river only experiments. The contours depict the 34.9 isohaline position, ranging from day 20 to 140 with 30 -day increments.

experiments are more or less similar, suggesting an estuarine channel flux. When the plumes reach the distance of $400 \mathrm{~km}$ from the estuary head, their velocities become notably dissimilar. This leads to an increased distance between their frontal positions. To verify the behavior of the plume as a function of river discharge in a more continuous fashion, we ran another set of experiments, changing the river out-flow intensity by smaller increments. The average speed of propagation of the plume head, as a function of river outflow, can be followed in the starred graph in Figure $4 \mathrm{~b}$; the speed of propagation increases as discharge increases. In our main experiments, the estimated values were $5.88 \mathrm{~km} . \mathrm{day}^{-1}\left(0.07 \mathrm{~m} . \mathrm{s}^{-1}\right)$ for R15, 7.84 $\mathrm{km} . \mathrm{day}^{-1}\left(0.09 \mathrm{~m} . \mathrm{s}^{-1}\right)$ for R25, and $11.35 \mathrm{~km} . \mathrm{day}^{-1}$ $\left(0.13 \mathrm{~m} . \mathrm{s}^{-1}\right)$ for R50. We note that the rate of increase of the velocity decreases with increased discharge, which suggests that for higher outflow regimes there is a weaker response (in terms of plume velocity) to an increase in river discharge. This can be seen in the first derivative for the velocity curve, depicted by the solid line in Figure $4 \mathrm{~b}$. An upshelf plume penetration (southwestward) was also noticeable in these experiments, achieving significant distances (more than $250 \mathrm{~km}$ ) along Argentinean coast (Fig. 3). The distance of this intrusion was also proportional to the river discharge magnitude. None of these plumes fully achieves an alongshore stationary position of the plume head during the simulations. However, with respect to offshore expansion, the plumes seem to achieve a limit. A considerable change in plume crossshore dimensions was noticed with increasing river discharge, but all cases eventually displayed a tendency toward a cessation of the offshore development. The differences in offshore extension can be verified by plotting plume cross-shore width as a function of time along two cross-shore transects, one at the estuary mouth, the other off the latitude of 
Lagoa Mirim (transects $\mathrm{J}=34$ and $\mathrm{J}=80$, in Figure $5 \mathrm{c}$ ). The result is shown in Figure 4c. On the northern transect $(\mathrm{J}=80)$, the 34.9 isohaline distance from the coast reaches $60 \mathrm{~km}$ for $\mathrm{R} 15,70 \mathrm{~km}$ for $\mathrm{R} 25$, and 110 $\mathrm{km}$ to R50. Along the southern transect $(\mathrm{J}=34)$, the cross-shore expansion stabilizes at approximately $360 \mathrm{~km}$ for $\mathrm{R} 15,420 \mathrm{~km}$ for $\mathrm{R} 25$, and $500 \mathrm{~km}$ for R50. Figure 5a shows the surface salinity distribution for the experiment with average river discharge (R25). That figure reveals the freshening of a region extending from the northern Argentinian coast to southern Brazil, in the form of a low salinity band. The main difference between this spatial distribution and the higher discharge case (not shown) was a further alongshore extension, with a more pronounced freshening of waters along the Brazilian inner shelf, and a wider offshore dislocation of the estuarine front. Figure 5 also shows the horizontal salinity distribution near the bottom (5b) and cross sections along three cross-shelf transects (5c). In spite of the wider cross-shore expansion of the plume at the ocean surface, the salinity field near the bottom was roughly confined by the 40-meter isobath. A similar situation was verified in experiments R15 and R50 (not shown here). The vertical distribution was stratified with positive slope of the salinity isopleths, as seen in the three transects $\mathrm{J}=34, \mathrm{~J}=80$ and $\mathrm{J}=122$ (Fig. 5c). The estuarine salinity configuration is evident along $\mathrm{J}=34$ where the 34.9 isohaline extends $450 \mathrm{~km}$ from the estuary head. To the north of the estuary mouth, the isohaline configuration is consistent with an alongshore flux (northeastward) induced by geostrophic adjustment.

Near the estuary head, the flow is nearly straight, following the main channel. The flow regime changes when low-salinity water reaches the sea and starts to accumulate, forming a large bulge. This region displays a complicated meandering pattern, showing vortices with diameters of approximately $35 \mathrm{~km}$ and velocities of about 0.125 $\mathrm{m} . \mathrm{s}^{-1}$, as indicated by transect $\mathrm{J}=34$ in Figure 6 . The transition between this meandering field and the coastal body is smooth, within $200 \mathrm{~km}$ north of the estuary axis. In this zone, a surface coastal jet develops. At the core of the $\mathbf{J}=80$ transect, northeastward alongshore velocities up to $0.2 \mathrm{~m} . \mathrm{s}^{-1}$ are found. This velocity decreases to the north, decaying to less than $0.1 \mathrm{~m} \cdot \mathrm{s}^{-1}$ across transect $\mathrm{J}=122$. Underneath the surface jet, a weak counter current is observed near the bottom on transect $\mathrm{J}=80$. It is mainly composed of slightly diluted near-bottom waters, and $-0.025 \mathrm{~m} . \mathrm{s}^{-1}$ speed southwestward. In simulations R15 and R50 the circulation followed almost the same general pattern, differing only in terms of magnitude, being $0.13 \mathrm{~m} \cdot \mathrm{s}^{-1}$ and $0.25 \mathrm{~m} . \mathrm{s}^{-1}$ respectively, for surface velocities (across $J=80$ ), and $-0.023 \mathrm{~m} . \mathrm{s}^{-1}$ and $-0.035 \mathrm{~m} \cdot \mathrm{s}^{-1}$, respectively for bottom velocities $(\mathrm{J}=80)$.
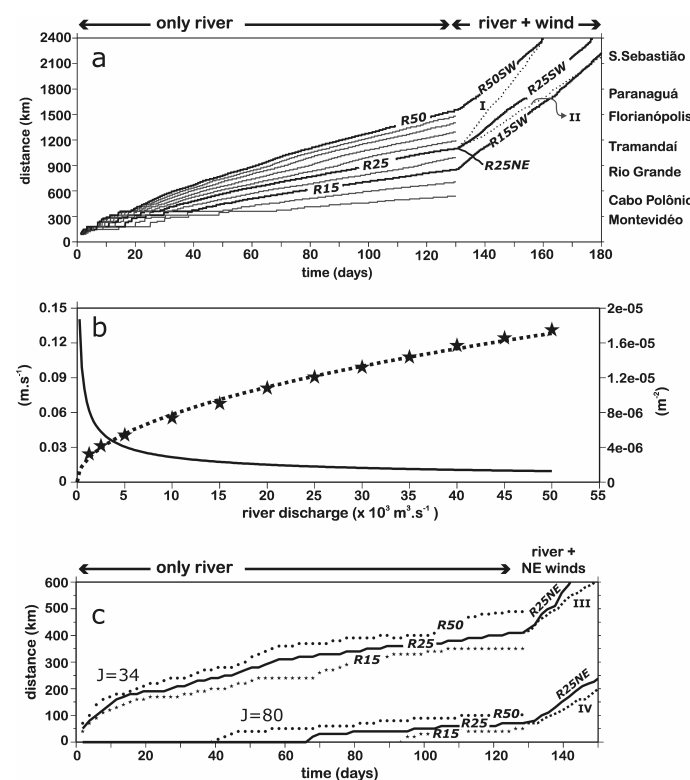

Fig. 4. a) Alongshelf plume penetration from the estuary head as a function of time for all numerical experiments. b) Average velocity of plume propagation as function of river discharge only (denoted by the stars). The thin dashed line represents a regression to the data in the form of a power curve (std=0.0022; $\left.\mathrm{R}^{2}=0.9954\right)$, while the solid line represents its first derivative. (c) Cross-shore plume width for river only experiments and simulations under upwellingfavorable winds (the cross-sections are indicated on Figure $6)$.

Experiments Forced With Wind and River Discharge

In this second group of simulations, initialization files from the river forcing experiments were used to start the runs. For this new set, we selected all three (R15, R25 and R50) discharge experiments. These new simulations started on day 130. The river discharge was kept constant since the initialization, while the wind forcing was ramped up within one inertial period. After initialization, the winds were kept constant in time and throughout the domain. The plume response to different alongshore wind directions was tested. Since the grid was rotated $40^{\circ}$ with respect to the north, we assumed NE and SW winds to be coincident with the domain's meridional axis. The main wind experiments were forced with 8 $\mathrm{m} . \mathrm{s}^{-1}$ wind speed, for both northeasterly and southwesterly cases. This corresponds to $\left|\tau_{\mathrm{y}}\right|=10^{-4} \times \mathrm{m}^{2} . \mathrm{s}^{-2}$, where $\tau_{\mathrm{y}}$ is the wind stress divided by the water density. For convenience, we will refer to these experiments as R15NE, R25NE and R50NE, respectively, for low, medium and high discharge northeasterly wind simulations, and R15SW, R25SW and R50SW, respectively, for low, medium and high 


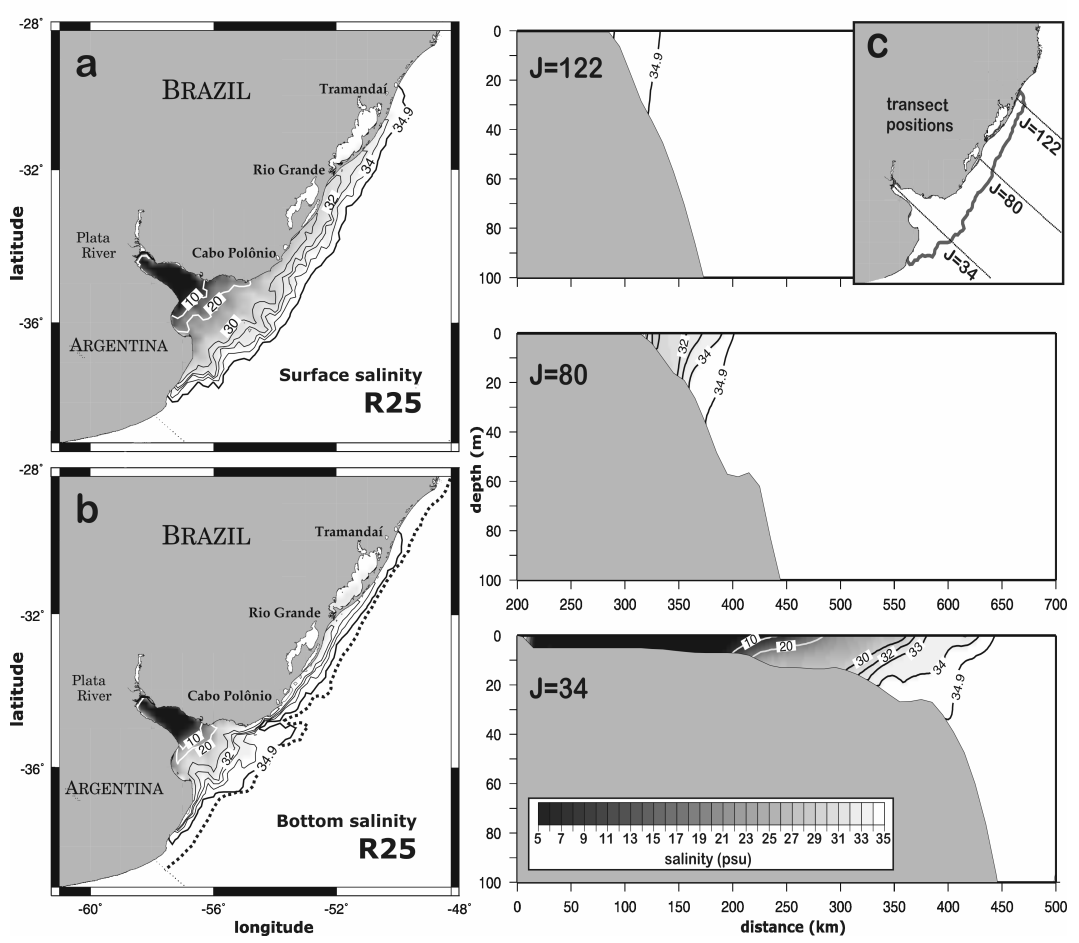

Fig. 5: Surface (a) and bottom (b) salinity fields for R25 river only experiment after 140 days of simulation. c) salinity transects for the same experiment. The $40 \mathrm{~m}$ isobath is depicted by a dashed line on "b". Salinity is depicted by the contours 10, 20, 30, 32, 33, 34 and 34.9 PSU, as well by a shade from fresh (black) to salt (white) waters.

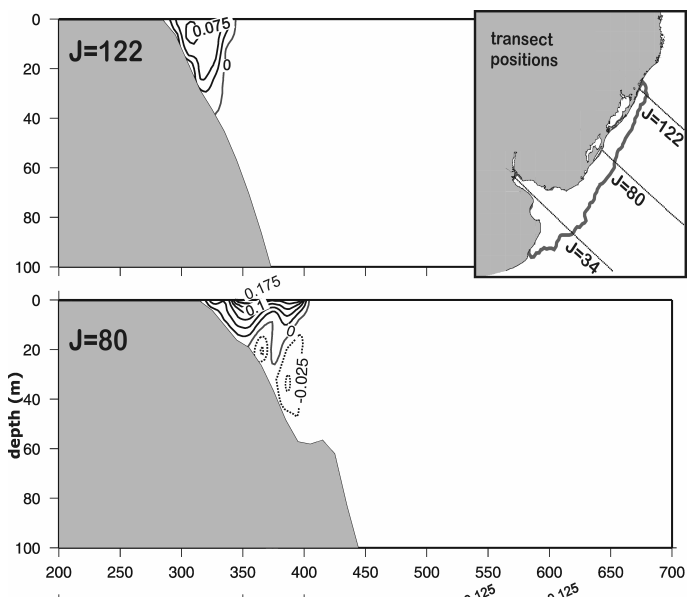

Fig. 6. Meridional velocity field for R25 river only experiment at day 140 . Contour intervals are between -0.2 and $0.2 \mathrm{~m} . \mathrm{s}^{-1}$ with 0.025 increment. Negative velocities are depicted by dashed lines.

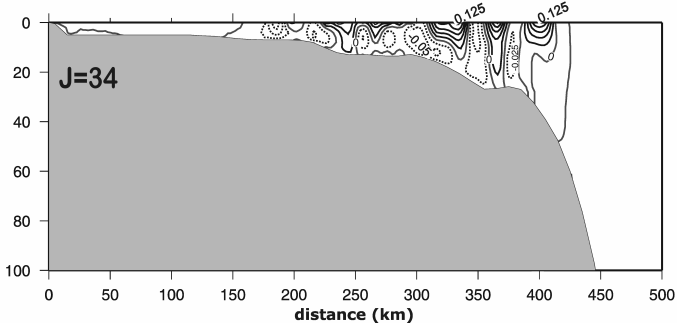


discharge southwesterly wind simulations. In the southwesterly wind case, two other wind magnitudes were used to force the model, referred to as weaker (6 $\left.\mathrm{m} . \mathrm{s}^{-1} \sim \tau_{\mathrm{y}}=-5 \times 10^{-5} \mathrm{~m}^{2} . \mathrm{s}^{-2}\right) \quad$ and stronger $\quad(15$ $\left.\mathrm{m} . \mathrm{s}^{-1} \sim \tau_{\mathrm{y}}=-3 \times 10^{-4} \mathrm{~m}^{2} . \mathrm{s}^{-2}\right) \quad$ southwesterly winds experiments. The $\tau_{\mathrm{x}}$ component was set to zero in all simulations.

\section{Southwesterly Wind Experiments}

In this set of experiments, we applied the socalled downwelling winds over low, medium and high discharge plumes for 50 days. We will first describe the evolution of the 34.9 surface isohaline along the coast as a function of time for the main wind experiment (Fig. 7). We will then focus on the differences imposed by wind magnitude. As an initial condition, the plume in the low discharge experiment (R15SW) extends $850 \mathrm{~km}$ from the estuary to Rio Grande $\left(32^{\circ} \mathrm{S}\right)$; in the average discharge experiment $(\mathrm{R} 25 \mathrm{SW})$ the plume head is near Tramandaí $\left(30^{\circ} \mathrm{S}\right)$, approximately $1100 \mathrm{~km}$ from the mouth; and in the high discharge experiment (R50SW) the head is located about $450 \mathrm{~km}$ farther upcoast, near $27^{\circ} \mathrm{S}$.

Ten days after southwesterly winds were applied, the plume in all three experiments extended approximately $240 \mathrm{~km}$ northeastward of their initial positions, reaching Tramandaí for R15SW, Santa Marta Cape $\left(28.3^{\circ} \mathrm{S}\right)$ for $\mathrm{R} 25 \mathrm{SW}$ and $25.2^{\circ} \mathrm{S}$ for R50SW (near Paranaguá). A significant modification in the offshore expansion of the plume's bulge was noted, with a contraction of the low salinity region towards the estuary. After 20 days, the high discharge plume shifted about $275 \mathrm{~km}$ farther up-coast and reaches the middle portion of the South Brazil Bight at $23.8^{\circ} \mathrm{S}$. In R25SW, the plume head was located at $26.2^{\circ} \mathrm{S}, 450 \mathrm{~km}$ downcoast, and on R15SW it was found at the latitude of Santa Marta Cape. After 30 days of southwesterly wind forcing, the plume in the R25SW experiment entered SBB, east of Paranaguá, while on R50SW experiment the plume occupied almost all SBB domain. The plume head reached the middle of the bight in R25SW and R15SW, after 40 and 50 days of simulation respectively. These

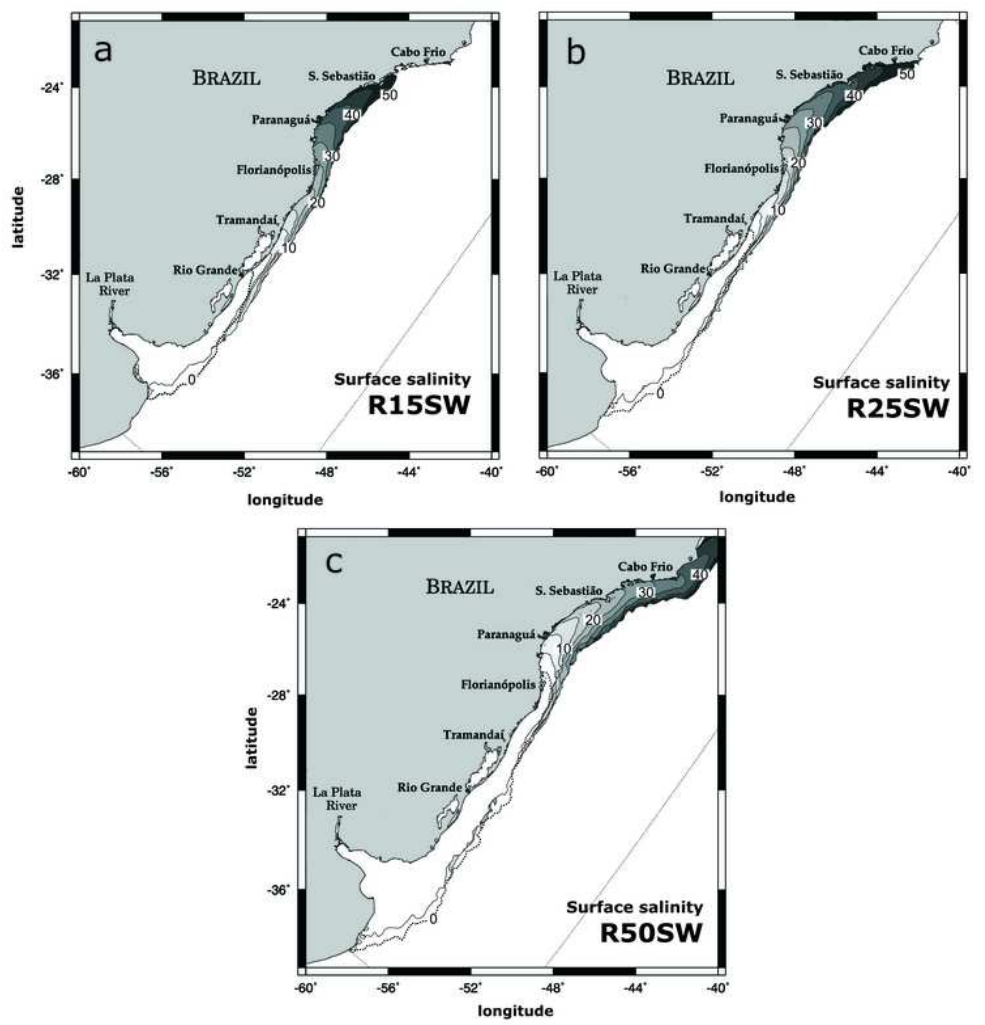

Fig. 7. Surface salinity field evolution for R15SW, R25SW and R50SW downwelling-favorable wind experiments $\left(8 \mathrm{~m} \cdot \mathrm{s}^{-1}\right.$ magnitude). The contours depict the 34.9 isohaline position with 5-day increments. 
differences in plume extension with and without winds are summarized in Figure 4a. After day 130, the application of downwelling winds led to a substantial modification of the plume's propagation speed for all river discharge conditions, with an average velocity of $27.16 \mathrm{~km} . \mathrm{day}^{-1}\left(0.31 \mathrm{~m} . \mathrm{s}^{-1}\right.$, about 2 to 4.5 times faster than the river only cases). In an attempt to evaluate the influence of wind strength in alongshore velocity of the plume, two additional downwelling experiments were performed for all river outflows, with stronger and weaker southwesterly winds $\left(15 \mathrm{~m} \cdot \mathrm{s}^{-1}\right.$ and 6 $\left.\mathrm{m} . \mathrm{s}^{-1}\right)$. The plume propagation speed was 21.93 $\mathrm{km}^{-1 \mathrm{day}^{-1}}\left(0.25 \mathrm{~m} . \mathrm{s}^{-1}\right)$ and $42.22 \mathrm{~km}^{-\mathrm{day}^{-1}}(0.49$ $\left.\mathrm{m} . \mathrm{s}^{-1}\right)$, respectively, for the weaker and stronger wind experiments. A summary of the results in all southwesterly cases is shown in Table 1 . The plume propagation speed was independent of the river outflow. In Figure $4 \mathrm{a}$ we observe the along coast evolution in these two additional wind experiments for an average river outflow magnitude. The dashed line represents stronger (denoted by the numeral I) and weaker (denoted by II) wind cases. Since the propagation speed was independent of river outflow magnitude, similar paths for the other experiments can be found by drawing parallel lines from the end of the simulation forced only with river outflow. A surface salinity field, when the plume reaches the S. Sebastião latitude, is presented in Figure 8 for the main wind experiments ( $8 \mathrm{~m} \cdot \mathrm{s}^{-1}$ southerly winds), where R25SW displays its 40th day of simulation (top panel) while R50SW is in its $25^{\text {th }}$ day (bottom panel). Both plumes extended more than $2000 \mathrm{~km}$ from the Plata estuary. Although representing different situations, these experiments were very similar in a general way. In its central part, between the Uruguay coast and Florianópolis, the low salinity band was composed mainly by 20 to 30 PSU waters that displayed crossshore salinity gradients. Salinities below 20 PSU remained mostly confined to the estuary, whereas higher alongshore salinity gradients were observed near the head of the plume. Small low salinity pools were frequently detached at the estuary and near the Uruguay coast in these simulations. Other downwelling wind experiments produced only slightly different surface-salinity configurations. In Figure 9 we observe R25SW salinity transects after 40 days of southwesterly winds. The inclined configuration of isohalines observed in the outflow only experiment was replaced by a cross-shore salinity gradient, with a lack of vertical salinity stratification (see vertical isohalines in transects $\mathrm{J}=80, \mathrm{~J}=122$ and $\mathrm{J}=202$ ). The plume widened beyond the $60 \mathrm{~m}$ isobath. At the estuary domain $(\mathrm{J}=34)$ there was a retraction of the plume body and an enhancement of the salinity gradients. This configuration was different from the outflow only simulations, where the front occupied the whole estuary. In transects $\mathrm{J}=34$ and $\mathrm{J}=80$, we observe surface buoyant pools detached from the plume's main body, with a length scale of $30 \mathrm{~km}$.

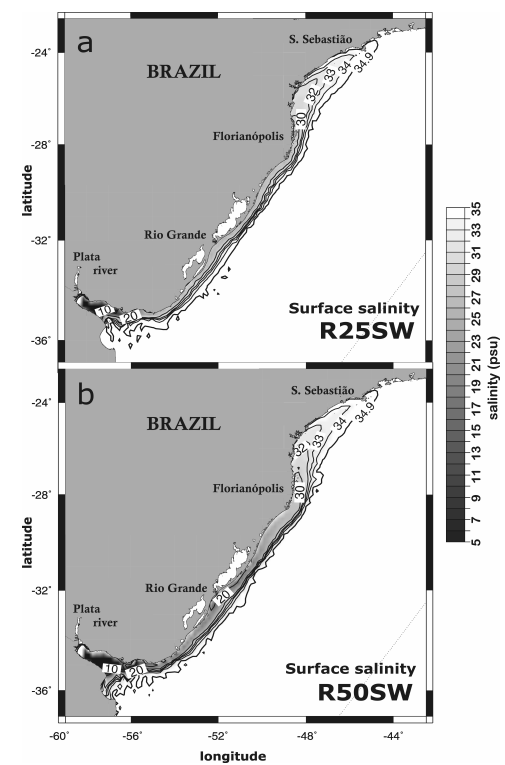

Fig. 8. Surface salinity fields for downwellingfavorable wind experiments with average discharge outflow after 40 days of wind forcing (top panel) and extreme river discharge after 25 days of wind (bottom panel). Salinity is depicted by the contours of 10,20 , $30,32,33,34$ and 34.9 PSU as well by the shade ranging from fresh (black) to salt (white) waters.
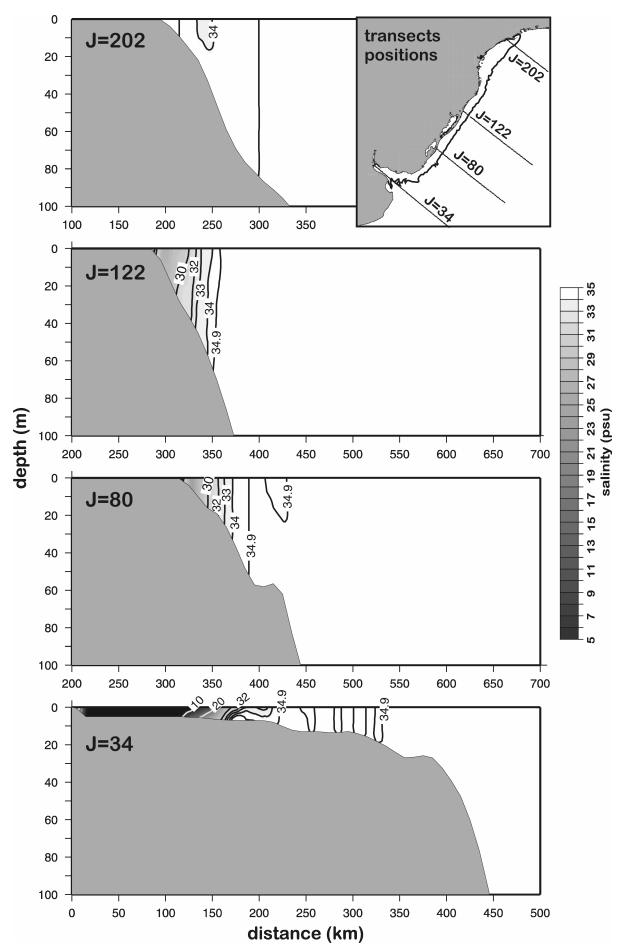

Fig. 9. Salinity transects for R25SW after 40 days of wind forcing with $8 \mathrm{~m} . \mathrm{s}^{-1}$ strength. 
This rapid extension of the low-salinity signal along the coast is a result of advection promoted by a barotropic flux over the shelf. The downwelling wind induced a surface Ekman transport towards the coast, accumulating water in the nearshore region. This was enhanced near the estuarine zone, where higher surface elevations were observed against the Uruguayan coast, achieving magnitudes of $0.25 \mathrm{~m}$, $0.40 \mathrm{~m}$ and $0.8 \mathrm{~m}$, respectively, for the weak, medium and strong wind cases. Along the southern Brazilian coast, the elevation varied between 0.15 and $0.5 \mathrm{~m}$, while along the SBB the largest elevation did not exceed $0.45 \mathrm{~m}$ for the stronger wind case. The elevation pattern followed closely the depths over this region for all cases, revealing the confinement of the flux on the shelf.

This piling up of water creates a positive cross-shore pressure gradient which is governed by Coriolis adjustment producing a strong and well defined northeastward current. In Figure 10 we observe the alongshore velocity component for four transects in the domain after 20 days of SW wind

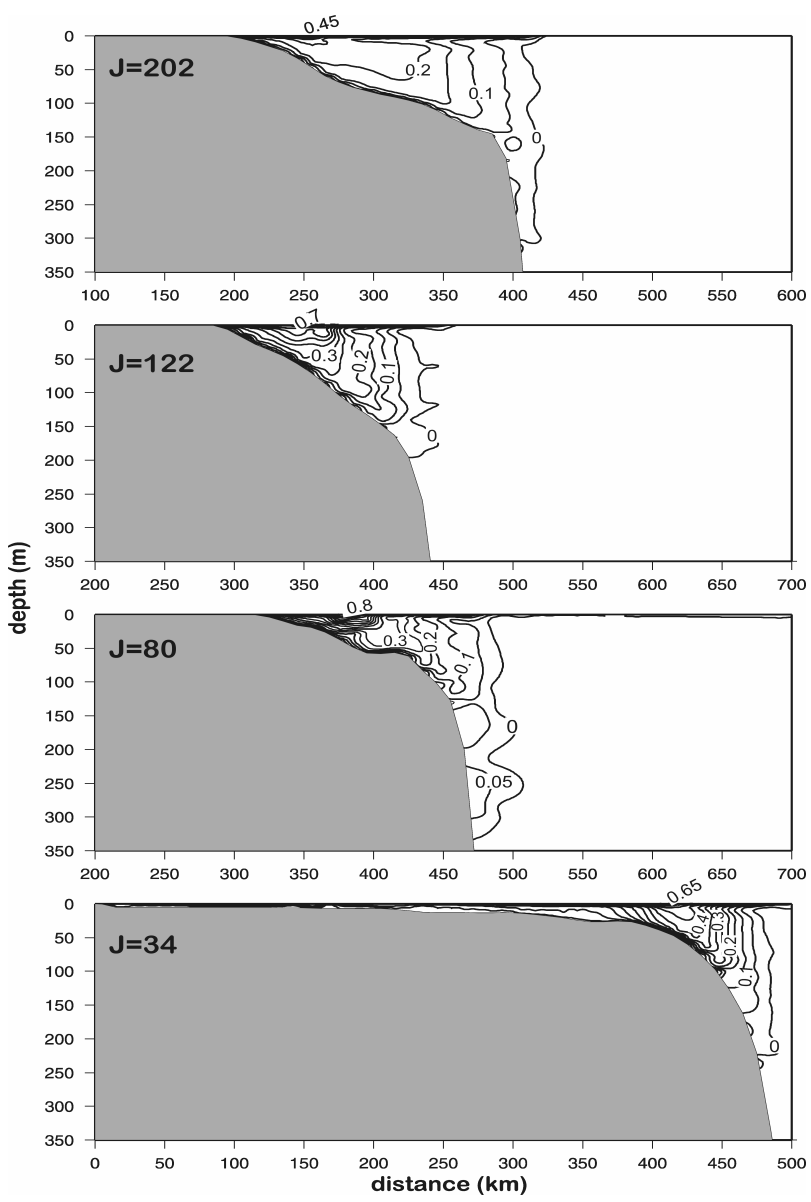

forcing. A definite barotropic signal is found on the continental shelf, nearly bounded by the $250-300 \mathrm{~m}$ isobaths. This current started on the southern boundary, traveled through the north Argentinian, Uruguayan, and Brazilian shelves. A greater intensification occurred on transects $\mathrm{J}=80$ and $\mathrm{J}=$ 122 for south Brazilian shelf. Currents achieved velocities of $0.8 \mathrm{~m} . \mathrm{s}^{-1}$ and $0.7 \mathrm{~m} . \mathrm{s}^{-1}$, respectively, in the core, but mostly reached the average value of 0.1 $0.3 \mathrm{~m} . \mathrm{s}^{-1}$ on middle and outer shelves. Wider currents in the northern and southern shelf transects achieved $0.45 \mathrm{~m} . \mathrm{s}^{-1}$ and $0.65 \mathrm{~m} . \mathrm{s}^{-1}$, respectively, in their core. Transect $\mathrm{J}=202$ had the smallest alongshore velocity gradient across the shelf. In other wind experiments, currents achieved maximum values of $1.0 \mathrm{~m} . \mathrm{s}^{-1}$ and $0.55 \mathrm{~m} . \mathrm{s}^{-1}$, respectively, for the weak and strong wind cases. In the estuarine zone, the current followed the bathymetry, making a wide turn and entering the region immediately outside of the Plata estuary. This current shear was responsible for the detachment and advection of small low-salinity pools (Fig. 9, J=34).
Fig. 10. Meridional velocity $\left(\mathrm{m} \cdot \mathrm{s}^{-1}\right)$ transects for R25SW after 20 days of wind forcing with $8 \mathrm{~m} \cdot \mathrm{s}^{-1}$ strength. 


\section{Northeasterly Wind Experiments}

Northeasterly (upwelling favorable) winds were applied over developed plumes as in the previous experiments, but for $6 \mathrm{~m} . \mathrm{s}^{-1}$ and $8 \mathrm{~m} . \mathrm{s}^{-1}$ wind values. The model was run for 20 days. The surface-salinity fields for days 5 and 10 are shown in Figure 11 for average and high outflow cases under $8 \mathrm{~m} . \mathrm{s}^{-1} \mathrm{NE}$ winds. The plume responded to wind forcing within a few days with a significant offshore spread. Within 5 days, a considerable offshore dislocation was produced. For both the river discharge cases the plumes extended $45 \mathrm{~km}$ offshore. After 10 days of wind forcing, the coastal plume achieved almost twice its original cross-shore width. The plume separation from the coast increased at the plume nose and on the southern Uruguayan shelf. For the high discharge case, the separation also occurred on southern Brazilian coast east of Rio Grande. On day 15 (not shown) the plume detachment continued, and at the end of the simulation its body was completely separated from the coast. The plume offshore drift may be seen by the evolution of the low-salinity signal in the estuary mouth and Lagoa Mirim salinity transects on R25NE (Fig. 4c) for both wind magnitudes. The plume grew offshore in an approximately linear fashion, doubling its width on the northern transect $(\mathrm{J}=80)$ after 10 days of wind forcing. The average growth was similar for other river outflows on the estuarine transect: 8 $\mathrm{km}$ day $^{-1}$ for $6 \mathrm{~m} . \mathrm{s}^{-1}$ winds (dashed lines with numerals III and IV) and near $15 \mathrm{~km}^{\mathrm{day}}{ }^{-1}$ for $8 \mathrm{~m} . \mathrm{s}^{-1}$ winds (continuous lines). The velocities were the same for the high outflow case on $\mathrm{J}=80$, although for the average and lower outflow cases they diminished after some time (i.e., once the plume nose started to get closer to the transect position). In terms of along coast retraction, the modification is clear in all $\mathrm{NE}$ wind

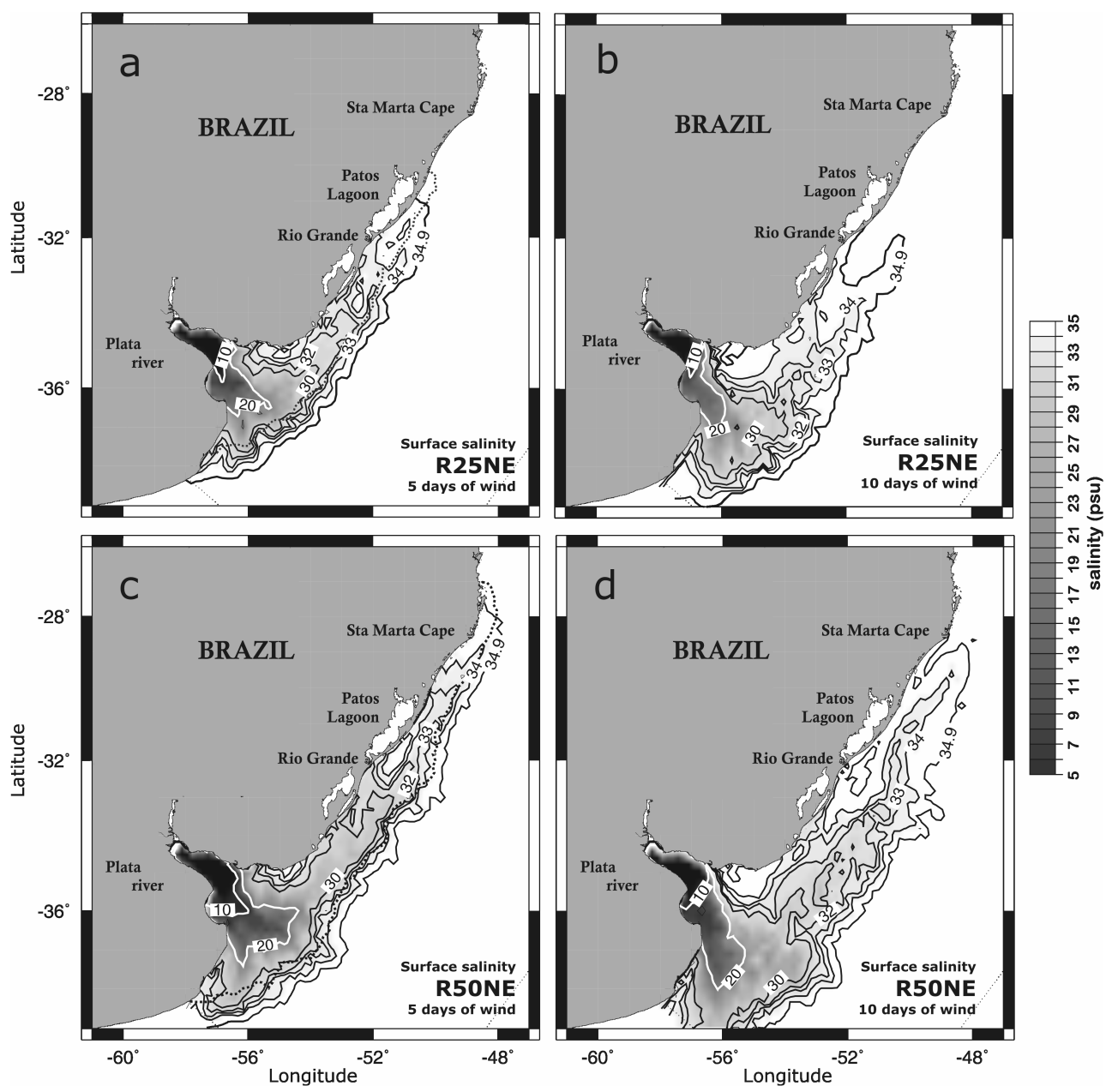

Fig. 11. Surface salinity field after 5 and 10 days under upwelling-favorable wind forcing with average $(\mathrm{a}, \mathrm{b})$ and extreme outflow (c,d). The dashed line represents the initial 34.9 isohaline position. 


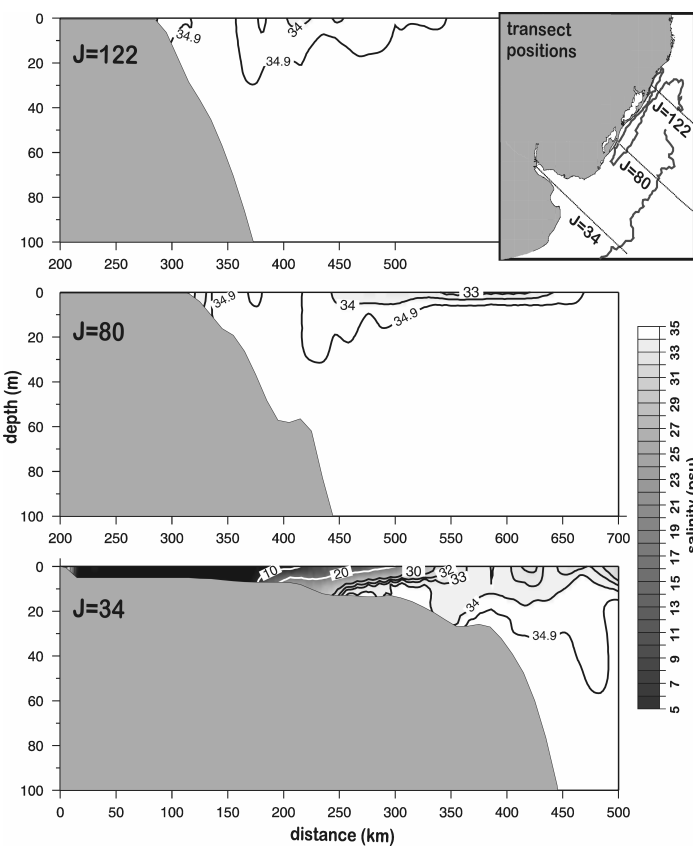

Fig. 12. Salinity transects for R25NE after 15 days of wind forcing.

experiments. Promoted by a southwestward shelf current, this retraction could reach approximately -18 $\mathrm{km} \cdot \mathrm{day}^{-1}$ for $8 \mathrm{~m} \cdot \mathrm{s}^{-1}$ winds and $-12 \mathrm{~km} \cdot \mathrm{day}^{-1}$ for 6 $\mathrm{m} . \mathrm{s}^{-1}$ winds, on average and high outflow cases during the first 10 days. But once these plume bodies departed from the coast and from the shelf current, their southward rate of propagation was diminished. For example, we can follow the alongshore path evolution measured by the model for the average river discharge case under $8 \mathrm{~m} . \mathrm{s}^{-1}$ winds (Fig. 4a, depicted as R25NE). The difference between river outflow-only and the northeastward experiment regimes was noticed by the curve break on this graph. About 10 days after northeasterly winds were applied the main plume body was detached $100 \mathrm{~km}$ from the coast (Figs $11 \mathrm{~b}$ and 11d), and only a narrow low-salinity strip remained attached to the coast (Fig. 12). The main plume body was 10 to $15 \mathrm{~m}$ thick, while the coastal strip extended throughout the water column between the coast and the $10 \mathrm{~m}$ isobath. In the estuary domain the northeasterly winds dislocated the plume offshore in the first 5 days. After that, a southwestward current developed and reversed the plume. As exemplified by 10 and 20 isohalines (Fig. 11), it changed its natural northward propagation for a southward drift. This shelf current occurred as a result of the geostrophic balance between the negative pressure gradient (developed by the offshore surface Ekman transport) and the Coriolis force. After 20 days, for both weaker and stronger winds, the near-coast water level decreased by -0.20 and $-0.55 \mathrm{~m}$ at the estuary and by -
0.20 and $-0.30 \mathrm{~m}$ on the south Brazilian shelf. The currents were about $-0.35 \mathrm{~m} . \mathrm{s}^{-1}$ for stronger winds $(8$ $\left.\mathrm{m} . \mathrm{s}^{-1}\right)$, and $-0.20 \mathrm{~m} \cdot \mathrm{s}^{-1}$ for weaker winds $\left(6 \mathrm{~m} \cdot \mathrm{s}^{-1}\right)$. The barotropic current follows the bathymetry southwestward, and flows through the southern boundary. Northeasterly winds led to significant and rapid extension of low salinity water along the coast south of the estuary.

\section{Discussion}

Fed by the second largest river system of South America with an average river runoff of $23 \times 10^{3} \mathrm{~m}^{3} \cdot \mathrm{s}^{-1}$ the Plata shelf plume's dimension surpass the internal Rossby radius and therefore is subject to earth rotation effects. The funnel shape of the estuary provides a gradual change between an estuarine channel and the inner shelf, with an increasing Kelvin number $(\mathrm{K}=\mathrm{b} / \mathrm{ri}$, where $\mathrm{b}=$ inlet breadth; ri= internal Rossby radius of deformation on the shelf) (Garvine, 1999). We observed distinctive circulation types along the estuarine axis that agree with the regime differentiation found in the numerical studies of Chao \& Boicourt (1986). These features were also qualitatively consistent to observations of Münchow \& Garvine (1993) for the Delaware plume, despite the differences in the spatial scale compared to the Plata. Inside the estuarine channel (first $200 \mathrm{~km}$ ), we found velocities consistently higher than those over the shelf. After leaving this "channel regime", the water flowed out of the estuary and traveled up-coast, but a considerable amount of energy seems to be accumulated near the estuary mouth, forming a large pool of mixed water. A "near flow field" characterized the anticyclonic surface flow and the formation of the estuarine bulge. The "far field" was characterized by the plume alongshelf intrusion.

Near/far field separation can be characterized by a strong cyclonic surface flow and downwelling (Chao \& Boicourt, 1986; Oey \& Mellor, 1993), and with a modification from a nearly inertial regime in the turning region, to a nearly geostrophic regime in the coastal current itself (Garvine, 1987; Münchow \& Garvine, 1993). Although no sharp distinction was observed in our simulations, the differentiation between near and far fields was apparent in river only experiments. In spite of this regime differentiation, the bulge surface area was related to outflow magnitude, and a meandering pattern was a common feature in this location.

The presence of upshelf intrusions or massive bulges such as those observed in our simulations are usually absent in field observations (Garvine, 2001). One exception is the upshelf intrusion observed of the Changjiang (Yangtze) river plume, as described by Beardsley et al. (1985). Fong \& Geyer (2002) attributed these differences to the effect of ambient shelf currents, which would be essential in the determination of the 
plume structure by models. Garvine (2001), on the other hand demonstrated that simulated plumes are highly sensitive to model configuration. Significant changes on bulge or in upshelf penetration may result from different schemes of outflow implementation. Despite of these findings, the formation of a bulge and the upshelf intrusion for the Plata simulations were consistent to historical hydrographic maps of Piola et al. (2000), and the salinity distributions of Guerrero et al. (1997a).

In terms of salinity distribution for the estuary, our simulations resembled quite well Guerrero et al. (1997a) and Piola et al. (2000) observations, where 10-20 PSU isohalines are located near Punta Rasa and Punta del Este. The vertical stratification and plume bottom confinement could also be reasonably reproduced, matching Guerrero et al. (1997a) mild wind synoptic situation. Our experiments also demonstrated a small but noticeable offshore shift of the estuarine front with increase of river outflow. Following an alongshore path toward northeast, with a coastal length varying from $850 \mathrm{~km}$ to $1550 \mathrm{~km}$ (respectively for low and high outflow only cases), the Plata exerted strong influence over the Uruguayan and South Brazilian shelves. The salinity fields in our river outflow only experiments corroborate Miranda (1972) analysis of coastal water mass formation, where a low salinity band near the South Brazil Shelf (SBS) was associated with Plata waters.

These results also agreed with the known seasonal salinity variability of the Plata plume (Piola et al., 2000). In summer, under the average discharge of $\mathrm{Q}=20 \times 10^{3} \mathrm{~m}^{3} \mathrm{~s}^{-1}$, the plume mean location stays near Rio Grande, while during the winter $\left(30 \times 10^{3} \mathrm{~m}^{3} \mathrm{~s}^{-1}\right)$ its influence extends to $27^{\circ} \mathrm{S}$ on the SBS. These positions depart to some extent from those in our outflow cases, but most of the differences may be attributed to wind seasonality.

Simpson \& Souza (1995) studying the action of tides upon a buoyancy-driven current demonstrated its effect on vertical mixing through elevated bottom stress and tidal straining of the stratified flow generated by the plume. Garvine (1999) investigated the effect of tidal amplitudes on the alongshelf penetration of a coastal buoyant plume in an idealized domain. A linear, inverse relationship suggested that regions dominated by extreme tidal amplitude (e.g. Bay of Fundy) are expected to have greatly reduced alongshelf penetrations. On the other hand, in continental shelves such as SBS where tides have small amplitude, plume intrusions are expected to be largely unaffected by them. In addition, Simionato et al. (2001) numerical simulations demonstrated that tides may play a role in the Plata plume mixing process, but mainly by smoothing the horizontal salinity structures.

The northeastward geostrophic flow along SBS was consistent with the modeling performed by Pereira (1989) and Ghisolfi \& McKee (2003) under thermohaline forcing. Our results also reinforce the findings of a buoyancy-driven current described by Zavialov et al. (1998) by means of a inverse model for circulation and by Soares \& Möller (2001) who computed northward residual flow from a current meter off Rio Grande shelf. The weaker countercurrent underneath the northeastward surface flow was also described in Ghisolfi \& McKee (2003). These resultant "two layer circulation" flows are a common feature in coastal plumes and may be recognized as the first mode of a baroclinic Kelvin wave (Chao, 1987; Garvine, 1999).

The plume's alongshelf average speed of propagation was linked to the outflow magnitude, but faster growth was observed for the lower river outflow magnitude. Apparently, the water accumulation at the bulge and plume cross-width growth compensate for the lack of increase in alongshore growth rate. We verified that even with high outflow, the river simulations could not explain penetrations beyond $27^{\circ} \mathrm{S}$. This model behavior motivated the exploration of wind forced simulations since winds play an important role in SBS currents. To study the plume response to steady winds, we carried out simulations that included alongshore winds under different river discharges. Downwelling winds induced an onshore plume contraction due to flux towards the coast. The water piling up near the coast leads to the establishment of an offshore pressure gradient and a northeastward current. This barotropic flow was responsible for the alongshore plume growth. Our results show that the mean intrusion velocities under wind forcing were independent of the river outflow magnitude. The effect of downwelling-favorable winds has been investigated by Chao (1987) using an idealized domain, Kourafalou et al. (1996b) for South Atlantic Bight (U.S.A), Hickey et al. (1998) for Columbia and Rennie et al. (1999) for Chesapeake plume. Their results displayed similar effects coherent to our observations: a reduction of the plume's surface area and a downcoast acceleration in a jet-like configuration. The resulting velocities over the shelf were consistent with the findings of Zavialov et al. (2002) on the SBS, who measured 0.6-0.8 $\mathrm{m} . \mathrm{s}^{-1}$ currents under strong alongshore winds. In some cases, the observed currents achieved $1.2 \mathrm{~m} . \mathrm{s}^{-1}$ at 15 $\mathrm{m}$ depth. Under persistent positive alongshore currents Zavialov et al. (2002) recorded a reduction of surface salinity from 35 to 30 PSU. These values were maintained for more than 30 days in late autumn.

Upwelling-favorable winds exerted very different effects. Regardless of the wind and outflow intensities, surface Ekman drift acted to separate the plume's body from the coast. Previous studies have demonstrated this response by means of field observations (Münchow \& Garvine, 1993; Sanders \& Garvine, 2001; Houghton et al., 2004) and numerical modeling (Chao, 1987; Kourafalou et al., 1996b; Fong \& Geyer, 2001). The offshore plume drift were 
comparable to findings of Houghton et al. (2004) for Delaware plume. The detachment from the coast agrees well with their observations and with the conceptual model proposed by Fong \& Geyer (2001). The persistence of winds with a strong upwelling component are likely to be an effective mechanism for dissipating the Plata plume and transferring shelf waters to the ocean. Kourafalou et al. (1996a) have shown how upwelling winds work on the exchange of materials from the continental shelf and Piola (2002) suggested this transfer of light water pools to the Brazil Malvinas Confluence as an effective and irreversible process of water mass exchange. Near the coast, simultaneously to the plume detachment occurred the upwelling of subsurface waters. This process seemed to be enhanced off the Uruguayan coast, where the effect of winds upon the shelf currents was also capable of reversing the river plume direction. This result was consistent with Mianzan et al., (2001) observations in the summer of 2000. In a period of anomalously low Plata outflow $\left(12 \times 10^{3} \mathrm{~m}^{3} \mathrm{~s}^{-1}\right)$ and strong northeasterly winds, high salinity waters (> 34) and Southern Brazilian marine biota (plankton and fishes) were observed in the outer Plata estuary.

In general, our results suggest that the distribution of low-salinity waters over the shelf is much more sensitive to wind direction than to the river outflow variability. Alongshore winds seem to determine the main role on the Plata plume alongshore growth or destruction. The effect of cross-shore wind components, as investigated in Pimenta (2001) have shown smaller importance on the plume control. Once intrusion velocities did not depend on the river discharge magnitude but mostly on the downwelling wind intensity, the possible intrusion of cold and fresh waters up to the SBB seems to be linked to three main factors: the initial alongshelf plume position (that might be determined by the river outflow), the intensity, and the persistence of the southwesterly wind events. Our simulations have show that the time scale necessary to advect the Plata waters to SBB by steady wind forcing and average river discharge, varied between 25 and 49 days, depending on the wind strength (Table 1). When constant, strong downwelling winds blow over a plume, with spatial extensions similar to the mean winter field described by Piola et al. (2000), this time scale can be even reduced to 15 days.
An important part of the shelf currents variance along the Southeastern America continental shelf is known to be attributed to the winds (Soares \& Möller, 2001; Zavialov et al., 2002; Pimenta et al., 2004). Cold fronts are responsible for strong southwesterly winds and for the generation of sea level oscillations that travels equatorward along the SBS and SBB in the form of continental shelf waves (Stech \& Lorenzzetti, 1992; Castro \& Lee, 1995). Unusual strong events might occur. Melo et al. (2003) describe an cyclone generated at Uruguay as responsible for raising sea level about $1 \mathrm{~m}$ and for generation of fairly strong northward currents $\left(1.6 \mathrm{~m} . \mathrm{s}^{-1}\right)$ at the Santa Catarina shelf. Indirect drift measurements registered around $27.7^{\circ} \mathrm{S}$ have also revealed persistent northward currents for 10 to almost 20 days in early May and June 2001 (Pimenta et al., 2004). Assireu et al. (2003) suggest that the drifter that accompanied the cold water intrusion of 1993 winter (described in Campos et al; 1996a) was also driven by continental shelf waves.

Rather than being the result of continuous wind forcing, plume intrusions might result from the passage of a sequence of cold fronts. Rennie et al. (1999) have demonstrated the effect of winds in the creation of a pulsed buoyancy current downstream of Chesapeake Bay \& Hickey et al. (1998) have shown sensitive responses of the Columbia plume to changes in wind speed and direction in the time scale of 2-10 days.

Since the Plata outflow was normal during the winter of 1993, the observations of anomalously cold, low salinity waters are probably attributed to southwesterly winds. Studies demonstrated up to a $50 \%$ increase in the formation of cyclones over Uruguay and San Matias Gulf (Argentina) during ENSO events (Satyamurty et al., 1990; Gan \& Rao, 1991). This conclusion is in agreement with recent analysis of historical hydrographic data and winds, which suggest that the winter 1993 southwesterlies were among the strongest since 1949 (Piola et al., 2005). Extreme events may arise from certain combinations of alongshore winds and outflow. Extreme northeastward penetrations of the Plata plume will be associated with large outflow and strong, sustained southwesterly winds, while extreme plume retractions will occur under low outflow and northeasterly winds.

Table 1. Necessary time under downwelling winds for the plume to reach $\mathrm{S}$. Sebastião $\left(\mathrm{t}_{\mathrm{ss}}\right)$ and alongshore average speed of propagation $\left(\mathrm{V}_{\mathrm{p}}\right)$ under different wind and river magnitudes.

\begin{tabular}{cccc}
\hline \hline $\mathrm{Q}\left(\mathrm{x} 10^{3} \mathrm{~m}^{3} \cdot \mathrm{s}^{-1}\right)$ & \multicolumn{3}{c}{$\mathrm{t}_{\mathrm{ss}}($ days $)$} \\
& $\tau_{\mathrm{y}}=-5 \times 10^{-5} \mathrm{~m}^{2} \cdot \mathrm{s}^{-2}$ & $\tau_{\mathrm{y}}=-10^{-4} \mathrm{~m}^{2} . \mathrm{s}^{-2}$ & $\tau_{\mathrm{y}}=-3 \times 10^{-4} \mathrm{~m}^{2} . \mathrm{s}^{-2}$ \\
\hline 15 & $>60$ & 48.5 & 30.7 \\
25 & 49.7 & 39.9 & 25.5 \\
50 & 28.2 & 23.1 & 15.1 \\
\hline $\mathrm{V}_{\mathrm{p}}\left(\mathrm{km}^{\mathrm{dayy}}{ }^{-1}\right) \rightarrow$ & $\sim 21.93$ & $\sim 27.16$ & $\sim 42.22$ \\
\hline
\end{tabular}




\section{Conclusions}

Numerical simulations, using the Princeton Ocean Model, revealed the effects of river discharge and wind forcing on the behavior of the Rio de la Plata plume along the continental shelf of southeastern South America. The results show that increased river outflows produce deeper northward penetration of the plume along the coast. However, in the absence of favorable winds, the time scales associated with the alongshore penetration of the plume are unrealistically long to explain intrusions in the SBB. On the other hand, the experiments with the inclusion of wind forcing reveal that the behavior of the plume is significantly more dependent on the wind pattern than on the magnitude of the river discharge. When the winds blow from the southwest, in a downwelling favorably configuration, the penetration of the plume along the coast happens in a very coherent way. From our results we infer that a combination of the persistence and strength of southwesterly winds might lead to very intense events, enhancing the plume penetration along the coast, which could explain the episodes of anomalous penetration of the plume into the South Brazil Bight.

\section{ACKNOWLEDGEMENTS}

We would like to thank Barun Sen Gupta and Richard Garvine for the suggestions to this manuscript. This work was supported by the Fundação de Amparo à Pesquisa do Estado de São Paulo (FAPESP), grants $94 / 3091-4$ and 96/4060-0, and by the Inter-American Institute for Global Change Research (IAI), grant CRN-061. The first author was supported also by a FAPESP graduate student fellowship (proc. 98/14647-4). J. Miller was supported by the Naval Research Laboratory and the Office of Naval Research Global.

\section{REFERENCES}

Assireu, A. T.; Stevenson, M. R. \& Stech, J. L. 2003. Surface circulation and kinetic energy in the SW Atlantic obtained by drifters. Continent. Shelf Res., 23:145-157.

Beardsley, R. C.; Limeburner, R.; Yu, H. \& Cannon, G. A. 1985. Discharge of the Changjiang (Yangtze River) into the East China Sea. Continent. Shelf Res., 4:57-76.

Blumberg, A. F. \& Mellor, G. L. 1987. A description of a three-dimensional coastal ocean circulation model. In: Heaps, N. S. (Ed.), Three-dimensional coastal ocean models. Wasnhington, DC., American Geophysical Union. 208p.

Campos, E. J. D.; Gonçalves, J. E. \& Ikeda, Y., 1995. Water mass characteristics and geostrophic circulation in the South Brazil Bight - Summer of 1991. J. Geophys. Res., 100 (C9):18537-18550.
Campos, E. J. D.; Ikeda, Y.; Castro, B. M.; Gaeta, S. A.; Lorenzzetti, J. A. \& Stevenson, M. R. 1996a. Experiment studies circulation in the Western South Atlantic. In: EOS Transaction, 77:253-259.

Campos, E. J. D.; Lorenzzetti, J. A.; Stevenson, M. R.; Stech, J. L. \& B., S. R. 1996b. Penetration of waters from the Brazil-Malvinas Confluence region along the South American continental shelf up to $23^{\circ} \mathrm{S}$. Acad. Brasileira de Ciências, 68(1):49-58.

Campos, E. J. D.; Lentini, C. A. D.; Miller, J. L. \& Piola, A. R. 1999. Interannual variability of the sea surface temperature in the South Brazil Bight. Geophys. Res. Letters, 26(14):2061-2064.

Castro, B. M. \& Lee, T. N. 1995. Wind-forced sea level variability on the southeast Brazilian shelf. J. Geophys. Res., 100 (C8):16045-16056.

Chao, S.-Y. 1987. Wind-driven motion near inner shelf fronts. J. Geophys. Res., 92 (C4):3849-3860.

Chao, S.-Y. 1988a. River-forced estuarine plumes. J. Phys. Oceanogr., 18:72-88.

Chao, S.-Y. 1988b. Wind-driven motion of estuarine plumes. J. Phys. Oceanogr., 18:1144-1166.

Chao, S.-Y. \& Boicourt, W. C. 1986. Onset of estuarine plumes. J. Phys. Oceanogr., 16:2137-2149.

Ciotti, A. M.; Odebrecht, C.; Fillmann, G. \& Möller, O. O. 1995. Freshwater outflow and Subtropical Convergence influence on phytoplankton biomass on the southern Brazilian continental shelf. Continent. Shelf Res., 15(14):1737-1756.

Csanady, G. T. 1984. Circulation induced by river inflow in well mixed water over a sloping continental shelf. J. Phys. Oceanogr., 14:1703-1711.

Depetris, P. J.; Kempe, S.; Latif, M. \& Mook, W. G. 1996. ENSO-Controlled flooding in the Paraná River (19041991). Naturwissenschaften, 83:127-129.

Fong, D. A. \& Geyer, W. R. 2001. Response of a river plume during an upwelling favorable wind event. J. Geophys. Res, 106 (C1):1067-1084.

Fong, D. A. \& Geyer, W. R. 2002. The alongshore transport of freshwater in a surface-trapped river plume. J. Phys. Oceanogr., 32:957-972.

Framiñan, M. B. \& Brown, O. B. 1996. Study of the Rio de la Plata turbidity front, Part I: spatial and temporal distribution. Continent. Shelf Res., 16 (10):1259-1282.

Gan, M. A. \& Rao, V. B. 1991. Surface cyclogenesis over South America. Mon. Weath. Rev., 119:1293-1302.

Garvine, R. W. 1987. Estuary, plumes and fronts in shelf waters: A layer model. J. Phys. Oceanogr., 17:18771896.

Garvine, R. W. 1999. Penetration of buoyant coastal discharge onto the continental shelf: A numerical model experiment. J. Phys. Oceanogr., 29:1892-1909.

Garvine, R. W. 2001. The impact of model configuration in studies of buoyant coastal discharge. J Mar. Res., 59:193-225.

Geyer, W. R.; Beardsley, R. C.; Lentz, S. J.; Candela, J.; Limeburner, R.; Johns, W. E.; Castro, B. M. \& Soares, I. D. 1996. Physical oceanography of the Amazon shelf. Continent. Shelf Res., 16:575-616.

Ghisolfi, R. D. \& McKee, W. D. 2003. The effects of the alongshore wind stress on the top-to-bottom front along the Southern Brazilian coast: a two-dimensional modelling approach. Continent. Shelf Res., 23:14011424. 
Grimm, A. M.; Ferraz, S. E. \& T., Gomes, J. 1998 Precipitation anomalies in Southern Brazil associated with El Niño and La Niña events. J. Climate, 11:28632880.

Guerrero, R. A.; Acha, E. M.; Framiñan, M. B. \& Lasta, C. A., 1997a. Physical oceanography of the Río de la Plata estuary, Argentina. Continent. Shelf Res., 17(7):727742.

Guerrero, R. A.; Lasta, C. A.; Acha, E. M.; Mianzan, H. W. \& Framiñan, M. B. 1997b. Atlas hidrográfico del Río de la Plata. Montivideo, Comissión Administradora del Río de la Plata - Instituto Nacional de Investigación y Desarrollo Pesquero, 109pp.

Hickey, B. M.; Pietrafesa, L. J.; Jay, D. A. \& Boicourt, W. C. 1998. The Columbia River plume study: Subtida variability in the velocity and salinity fields. J. Geophys. Res., 103(C5):10339-10368.

Houghton, R. W.; Tilburg, C. E.; Garvine, R. W. \& Fong, A. 2004. Delaware River plume response to a strong upwelling-favorable wind event. Geophys. Res. Letters, 31 (L07302).

Kourafalou, V. H.; Lee, T. N.; Oey, L.-Y. \& Wang, J. D. 1996a. The fate of river discharge on the continental shelf. 2. Transport of coastal low-salinity waters under realistic wind and tidal forcing. J. Geophys. Res., 101 (C2):3435-3455.

Kourafalou, V. H.; Oey, L.-Y.; Wang, J. D. \& Lee, T. N., 1996b. The fate of river discharge on the continental shelf. 1. Modeling the river plume and the inner shelf coastal current. J. Geophys. Res., 101(C2):3415-3434.

Lentini, C. A. D., Podestá, G. G., Campos, E. J. D. \& Olson, D. B., 2001. Sea surface temperature anomalies on the Western South Atlantic from 1982 to 1994. Continent. Shelf Res., 21(1):89-112.

Lentz, S. J. 1995. The Amazon river plume during AMASSEDS: Subtidal current variability and the importance of wind forcing. J. Geophys. Res., 100(C2):2377-2390.

Limeburner, R.; Beardsley, R. C.; Soares, I. D.; Lentz, S. J. \& Candela, J. 1995. Lagrangian flow observations of the Amazon River discharge into the North Atlantic. J. Geophys. Res. 100(C2):2401-2416.

Matsuura, Y. 1996. Probable causes of recruitment failure of the Brazilian Sardine population in the 1974/75 spawning season. South African J. Mar. Sci., 17:29-35.

Mechoso, C. R. \& Iribarren, G. P. 1992. Streamflow in Southeastern South America and the Southern Oscillation. J. Climate, 5:1535-1539.

Mellor, G. L. 1996. Users guide for a three-dimensional, primitive equation, numerical ocean model. Tech. rep., Program in Atmospheric and Ocean Sciences, Princeton University. 53 p.

Mellor, G. L. \& Yamada, T. 1982. Development of a tubulence closure model for geophysical fluid problems. Rev. Geophys Space Phys., 20(4):851-875.

Melo, E.; Pimenta, F. M.; Mendes, D. A. R.; Hammes, G. R. Araujo, C. E. S.; Franco, D.; Alves, J. H. G. M.; Barletta, R. C.; Souto, A. M. C.; Castelão, G. P.; Pereira, N. C. \& Branco, F. V. 2003. A real time, on-line coastal information program in Brazil. In: VI Conference on Coastal and Port Engineering in Developing Countries. Colombo, Sri Lanka, p. 14. (published in digital form on compact disc).

Mianzan, H. W.; Acha, E. M.; Guerrero, R. A.; Ramirez, F. C.; Sorarrain, D. R.; Simionato, C. \& Borus, J. 2001. South Brazilian marine fauna in the Rio de la Plata estuary: Discussing the barrier hypothesis. In: IX Congreso Latinoamericano de Ciências del Mar. p. 210.

Münchow, A. \& Garvine, R. W. 1993. Dynamical properties of buoyancy-driven coastal current. J. Geophys. Res., 98 (C11):20063-20077.

O'Connor, W. P. 1991. A numerical model for tides and storm surges in the Rio de la Plata estuary. Cont. Shelf Res., 11 (12):1491-1508.

Oey, L.-Y. \& Mellor, G. L. 1993. Subtidal variability of estuarine outflow, plume and coastal current: a model study. J. Phys. Oceanogr., 23:164-171.

Orlanski, I. 1976. A simple boundary condition for unbounded hyperbolic flows. J. Comput.Phys., 21:251269.

Palma, E. D. \& Matano, R. P. 2000. On the implementation of open boundary conditions for a general circulation model: The three-dimensional case. J. Geophys. Res., 105 (C4):8605-8627.

Pereira, C. S. 1989. Seasonal variability in the coastal circulation on the Brazilian continental shelf $\left(29^{\circ} \mathrm{S}-\right.$ $35^{\circ} \mathrm{S}$ ). Cont. Shelf Res., 9:285-299.

Pimenta, F. M.; Melo, E.; Franco, D. \& Zavialov, P. O. 2004. Assessment of Santa Catarina shelf currents through the analysis of indirect measurements. J. Coastal Res. SI, 39:651-655.

Piola, A. R. 2002. El impacto del Plata sobre la plataforma continental. In: Schnak, E. J. (Ed.), El Niño: sus impactos en el Plata y en la región pampeana. Vol. 1. Assoc. Bonaerense de Científicos, Fac. de Cs. Naturales y Museo de la Plata, La Plata, Argentina.

Piola, A. R.; Campos, E. J. D.; Möller, O. O.; Charo, M. \& Martinez, C. 1999. Continental shelf water masses off eastern South America $-20^{\circ}$ to $40^{\circ} \mathrm{S}$. American Meteorology Society, Boston, MA, pp. 9-12.

Piola, A. R.; Campos, E. J. D.; Möller, O. O.; Charo, M. \& Martinez, C. 2000. Subtropical Shelf Front off eastern South America. J. Geophys. Res., 105 (C3):6565-6578.

Piola, A. R.; Matano, R. P.; Palma, E. D.; Möller, O. O. \& Campos, E. J. D. 2005. The influence of the Plata River discharge on the western South Atlantic shelf. Geophys. Res. Letters, 32 (L01603).

Rennie, S. E.; Largier, J. L. \& Lentz, S. J. 1999. Observations of a pulsed buoyancy current downstream of Chesapeake Bay. J. Geophys. Res., 104 (C8):18227-18240.

Ropelewski, C. F. \& Halpert, M. S. 1987. Global and regional scale precipitation patterns associated with the El Niño/Southern Oscillation. Monthly Weather Review, 115:1607-1626.

Sanders, T. M. \& Garvine, R. W. 2001. Fresh water delivery to the continental shelf and subsequent mixing: An observational study. J. Geophys. Res., 106 (C11):2708727101.

Satyamurty, P.; Ferreira, C. C. \& Gan, M. A. 1990. Cyclonic vortices over South America. Tellus, 42 (A):194-201.

Simionato, C. G.; Dragani, W.; Meccia, V. \& Nuñez, M. 2004. A numerical study of the barotropical circulation of the Rio de la Plata estuary: sensitivity to bathymetry, the Earth's rotation and low frequency wind variability. Estuar. coast. Shelf Sci., 61:261-273.

Simionato, C. G.; Nuñez, M. N. \& Engel, M. 2001. The salinity front of the Río de la Plata - a numerical case study for winter and summer conditions. Geophys. Res. Letters, 28:2641-2644.

Simpson, J. H. \& Souza, A. J. 1995. Semidiurnal switching of stratification in the region of freshwater influence of the Rhine. J. Geophys. Res., 100(C4):7037-7044. 
Soares, I. \& Möller, O. O. 2001. Low-frequency currents and water mass spatial distribution on the southern Brazilian shelf. Continent. Shelf Res.; 21:1785-1814.

Stech, J. L. \& Lorenzzetti, J. A. 1992. The response of the South Brazil Bight to the passage of wintertime cold fronts. J. Geophys. Res., 97 (C6):9507-9520.

Stevenson, M. R.; Dias-Brito, D.; Stech, J. L. \& Kampel, M. 1998. How do cold water biota arrive in a tropical bay near Rio de Janeiro, Brazil? Continent. Shelf Res., 18:1595-1612.

Sunye, P. S. \& Servain, J. 1998. Effects of seasonal variations in meteorology and oceanography on the Brazilian sardine fishery. Fish. Oceanogr., 7 (2):89-100.

Zavialov, P.; Möller, O. \& Campos, E. 2002. First direct measurements of currents on the continental shelf of Southern Brazil. Continent. Shelf Res., 22:19751986.

Zavialov, P. O.; Ghisolfi, R. D. \& Garcia, C. A. E. 1998. An inverse model for seasonal circulation over the Southern Brazilian Shelf: Near-surface velocity from the heat budget. J. Phys. Oceanogr., 28:545-562.
Sources of Unpublised Material

Miranda, L. B. 1972. Propriedades e variáveis físicas das águas da plataforma continental do Rio Grande do Sul. Ph.D. thesis. Instituto Oceanográfico da Universidade de São Paulo. 127 p.

Pimenta, F. M. 2001. Estudo numérico da influência da descarga fluvial e dos ventos sobre dinâmica da pluma do Rio da Prata. Master's thesis, Instituto Oceanográfico da Universidade de São Paulo. 127 p.

(Manuscript received 22 June 2005; revised 23 September 2005; accepted 03 November 2005) 